\title{
Front Matter: Volume 11608
}

, "Front Matter: Volume 11608," Proc. SPIE 11608, Optics Frontiers Online 2020: Micro and Nanophotonics (OFO-4 2020), 1160801 (24 December 2020); doi: $10.1117 / 12.2590251$

SPIE Event: Optics Frontiers Online 2020: Micro and Nanophotonics (OFO-4 2020), 2020, Online Only 


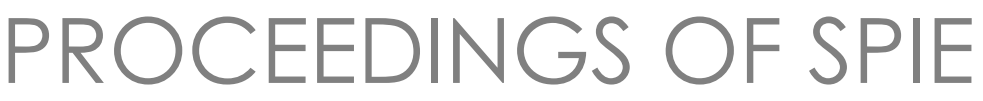

\section{Optics Frontiers Online 2020: Micro and Nanophotonics (OFO-4 2020)}

Hui Liu

Editors

25-27 June 2020

Virtual Event

Organized by

Chinese Laser Press (China)

Cosponsored by

The International Society for Optics and Photonics

Published by

SPIE 
The papers in this volume were part of the technical conference cited on the cover and title page. Papers were selected and subject to review by the editors and conference program committee. Some conference presentations may not be available for publication. Additional papers and presentation recordings may be available online in the SPIE Digital Library at SPIEDigitalLibrary.org.

The papers reflect the work and thoughts of the authors and are published herein as submitted. The publisher is not responsible for the validity of the information or for any outcomes resulting from reliance thereon.

Please use the following format to cite material from these proceedings:

Author(s), "Title of Paper," in Optics Frontiers Online 2020: Micro and Nanophotonics (OFO-4 2020), edited by Hui Liu, Proceedings of SPIE Vol. 11608 (SPIE, Bellingham, WA, 2020) Seven-digit Article CID Number.

ISSN: 0277-786X

ISSN: 1996-756X (electronic)

ISBN: 9781510640467

ISBN: 9781510640474 (electronic)

Published by

SPIE

P.O. Box 10, Bellingham, Washington 98227-0010 USA

Telephone +1 3606763290 (Pacific Time) · Fax +1 3606471445

SPIE.org

Copyright (c) 2020, Society of Photo-Optical Instrumentation Engineers.

Copying of material in this book for internal or personal use, or for the internal or personal use of specific clients, beyond the fair use provisions granted by the U.S. Copyright Law is authorized by SPIE subject to payment of copying fees. The Transactional Reporting Service base fee for this volume is $\$ 21.00$ per article (or portion thereof), which should be paid directly to the Copyright Clearance Center (CCC), 222 Rosewood Drive, Danvers, MA 01923. Payment may also be made electronically through CCC Online at copyright.com. Other copying for republication, resale, advertising or promotion, or any form of systematic or multiple reproduction of any material in this book is prohibited except with permission in writing from the publisher. The CCC fee code is $0277-$ $786 \mathrm{X} / 20 / \$ 21.00$.

Printed in the United States of America by Curran Associates, Inc., under license from SPIE.

Publication of record for individual papers is online in the SPIE Digital Library.

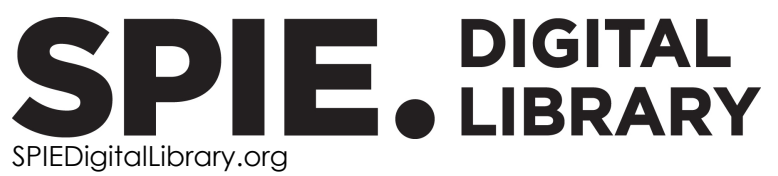

Paper Numbering: Proceedings of SPIE follow an e-First publication model. A unique citation identifier (CID) number is assigned to each article at the time of publication. Utilization of CIDs allows articles to be fully citable as soon as they are published online, and connects the same identifier to all online and print versions of the publication. SPIE uses a seven-digit CID article numbering system structured as follows:

- The first five digits correspond to the SPIE volume number.

- The last two digits indicate publication order within the volume using a Base 36 numbering system employing both numerals and letters. These two-number sets start with $00,01,02,03,04$, 05, 06, 07, 08, 09, OA, OB ... 0Z, followed by 10-1Z, 20-2Z, etc. The CID Number appears on each page of the manuscript. 


\section{Contents}

OPTICS FRONTIERS ONLINE 2020: MICRO AND NANOPHOTONICS (OFO-4 2020)

$1160802 \quad$ Non-spherical super-lens for surface plasmon [1 1608-1]

1160803 The effect of shell thickness on plasmonic behaviors of Ag@MoS 2 core-shell nanoparticles [11608-2]

1160804 Absorption and reflection properties of AZO grating with random textured surface in thin film solar cells [11608-3]

1160805 Comparison of trapping Rayleigh particles using focused canonical vortex beam and noncanonical vortex beam [11608-4]

1160806 Polarimetric multilongitudinal-mode fiber laser sensor for strain, temperature, and fiber birefringence measurement [1 1608-5]

1160807 Few-layer metasurface with gold split-rings for high-efficiency asymmetric circular polarization conversion [11608-7]

1160808 High-performance on-chip spectrometer based on micro-rings resonator [11608-8]

1160809 Enhancement in figure of merit of silver-gold bimetallic surface plasmon resonance sensor [11608-9]

$116080 \mathrm{~A}$ Lateral optical forces on two chiral nanospheres in plane waves of linear polarization [11608-10]

11608 OB Design of broadband achromatic metalens in the visible [11608-12]

11608 OC Microcavity structure based OCT fiber probe with controllable focal length [11608-13]

$116080 \mathrm{D}$ Rectifying the edge states by tuning the configuration of composite metal-dielectric particle chains [11608-14]

11608 OE Design of extreme ultraviolet quarter wave plate based on linearly chirped multilayer mirror [11608-15]

11608 OF Creation of a super diffraction limit focused spin hotspot by binary phase modulation [11608-16] 
Proc. of SPIE Vol. 11608 1160801-4

\section{Downloaded From: https://www.spiedigitallibrary.org/conference-proceedings-of-spie on 26 Apr 2023
Terms of Use: https://www.spiedigitallibrary.org/terms-of-use}

